Article

\title{
An Efficient HVAC Network Control for Safety Enhancement of a Typical Uninterrupted Power Supply Battery Storage Room ${ }^{\dagger}$
}

\author{
Mpho J. Lencwe*(D), SP Daniel Chowdhury*(D), Sipho Mahlangu, Maxwell Sibanyoni and Louwrance Ngoma \\ Department of Electrical Engineering, Tshwane University of Technology, Pretoria 0001, South Africa; \\ siphohlangus@yahoo.com (S.M.); mm.sibanyoni@webmail.co.za (M.S.); NgomaJL@tut.ac.za (L.N.) \\ * Correspondence: mpholencwe@gmail.com (M.J.L.); Spchowdhury2010@gmail.com (S.D.C.); \\ Tel.: +27-78-097-5204 (M.J.L.) \\ + This paper is an extended version of the research work presented at the 6th IEEE International Energy \\ Conference (ENERGYCon), Virtual, 28 September-1 October 2020; pp. 787-791.
}

check for updates

Citation: Lencwe, M.J.; Chowdhury, S.D.; Mahlangu, S.; Sibanyoni, M.;

Ngoma, L. An Efficient HVAC

Network Control for Safety

Enhancement of a Typical

Uninterrupted Power Supply Battery Storage Room. Energies 2021, 14, 5155 https://doi.org/10.3390/en14165155

Academic Editors: Pavlos

S. Georgilakis and Habib

M. Kammoun

Received: 29 June 2021

Accepted: 9 August 2021

Published: 20 August 2021

Publisher's Note: MDPI stays neutral with regard to jurisdictional claims in published maps and institutional affiliations.

Copyright: (c) 2021 by the authors. Licensee MDPI, Basel, Switzerland. This article is an open access article distributed under the terms and conditions of the Creative Commons Attribution (CC BY) license (https:// creativecommons.org/licenses/by/ $4.0 /)$.

\begin{abstract}
Lead-acid batteries utilised in electrical substations release hydrogen and oxygen when these are charged. These gases could be dangerous and cause a risk of fire if they are not properly ventilated. Therefore, this research seeks to design and implement a network control panel for heating, ventilation, and air conditioning system (HVACS). This is achieved by using a specific range of controllers, which have more than thirty loops of proportional, integral, and derivative (PID) control to achieve a cost-effective design. It performs the required function of extracting hydrogen and oxygen, maintaining the desired temperature of the battery storage room within recommended limits (i.e., $25 \pm 1^{\circ} \mathrm{C}$ tolerance) without compromising quality, as set out in the user requirement specification. The system control panel allows the user to access control parameters such as changing temperature set-points, fan-speed, sensor database, etc. It does this automatically and allows no human interface after all necessary settings and installation are completed. The hardware is configured to detect extreme hydrogen and oxygen gas content in the battery room and to ensure that the HVACS extracts the gas content to the outside environment. The system's results show that the network control panel operates effectively as per the recommended system requirements. Therefore, the effective operation of the HVACS ensures sufficient gas ventilation, thus mitigating the risk of fire in a typical battery storage room. Furthermore, this also enhances battery lifespan because of regulated operating temperature, which is conducive to minimise the effect of sulfation in lead-acid batteries (LAB). The extraction of toxic gases, regulation of temperature, ensuring suitable humidity in UPS battery room is important as it provides longer operational service of equipment, thus reducing frequent maintenance in these rooms. This benefits the electricity supply industry and helps in saving for unplanned maintenance costs.
\end{abstract}

Keywords: air-handling unit; battery room; HVACS; network control panel; intrinsic safe barrier module

\section{Introduction}

This research is an extension of the work originally presented at the International Energy Conference (ENERGYCon), 2020 [1]. Electrical substation designs can be classified as stationary, offshore, and modular. The offshore substations comprise upper construction, which has battery room on the third layer. In this study, the battery room is separate from other rooms in the electrical substation. Battery rooms are included for the regulation of switchgear's or uninterrupted power supply (UPS) systems, thus guaranteeing that a consistent energy source is always accessible during stand-in or extra operation requirements [2]. The global market of consumer batteries has increased significantly since the year 2017, with Europe and China being the leading consumers. This global capacity reached $103 \mathrm{GW}-\mathrm{h}$ in 2017 and is expected to reach $278 \mathrm{GW}-\mathrm{h}$ by the end of 2021 [3]. Lead-acid batteries are normally utilized in substation rooms due to the advantage of 
little care requirement [4]. These lead-acid batteries (LABs) release hydrogen and oxygen during charge, which is ignitable if it accumulates beyond limits. Because of these reasons, battery rooms are considered hazardous areas. Furthermore, at very high temperatures, these batteries can cause fire [5]. Subsequently, battery lifespan and performance reduce significantly at very low temperatures [6]. Hence, heating ventilation and air conditioning (HVAC) systems are necessary for these rooms to ensure low gas concentration and appropriate temperature levels. The installation of HVAC systems has grown significantly year-on-year in the last 20 years [7]. HVACs can be classified as air-handling units (AHUs). Their purpose is to provide quality new airborne, chilling, space heating, consumption air purification, and hu/de-modification. Through proper regulation of AHUs, the dehumidification could assist the battery room environment to sustain its conditions [8]. The HVACs are usually integrated with overpressure systems and chemical filtration, and they connect to the fire and gas system to adhere to safety regulations [9]. These units also operate in circulation unless gas detection in battery rooms reaches greater levels $(10 \%$ of LFL and $15 \mathrm{ppm}$ of $\mathrm{H}_{2} \mathrm{~S}$ ). HVACs could be checked and regulated through the panel, thus defining an operation arrangement primarily in the design phase is important $[10,11]$. In the case of fire-fighting functions, the air inlet and outlet ports in each room where the fire is detected, and in a carbon dioxide protection zone compartment, the HVAC control panel has to provide the electric damper with a command to automatically close, and switch off before the fire extinguishing agent radiates. This is to ensure an appropriate carbon dioxide concentration within the room [12]. In contrast, HVACSs have emerged as major energy consumers [13]. However, the conventional forced-air systems that currently operate in buildings stay not entirely recognized. Furthermore, AHUs remain continuously static towards a specifically desired target despite dynamic changes of working situations [14]. The applied controls are not optimized because they use rule-based control methods. These control methods are static and differ only by pre-set schedules and seasonal changes. On the one hand, human capacity is required to continuously monitor HVACS behavior and adjust it dynamically during operation [15]. Consequently, identifying and developing complete equations for designing the control system using conventional methods is difficult and almost unachievable [8].

In [15], a framework of achieving optimal control using long short-term memory for AHUs is proposed to estimate the practical HVAC action and build deep reinforcement learning algorithms training for the environment. The study uses two years of building automation system data as an evaluation testbed. The results show a 0.0015 mean square error when using the first-year data across 16 normalized AHU parameters. Deep reinforcement learning results show $27-30 \%$ saving of energy compared to the energy consumption of the conventional system and sustained $10 \%$ of the predicted percentage of discomfort (PPD). Liu et al. [16] evaluates five layouts to reduce power consumption in AHUs. The results show that the air-air heat exchangers affect the power consumption of the coils. Time-averaged ventilation control was proposed by Kaam et al. [17] to reduce extreme use of energy and decrease the risk of overcooling the areas that have HVACs. The results show that the average region airflow segment is reduced as of $0.44-0.27$ through the involvement time of operation. Besides, normal space heating, chilling, and power of the fan are reduced to 41,23 , and $15 \%$, respectively.

Li et al. [18] models and applies a prediction neural network (TDNN) and the Elman network neural (ENN) method aimed at inside temperature delay retort using period-lag. This study is conducted because of the difficulty in building accurate models caused by lag response characterization in regulating indoor temperature. The study uses a variableair-volume (VAV) airborne acclimatizing scheme as a training base. Thus, the results show that Elman network neural is an improved approach and can operate as intended for indoor temperature predictions because of the advantages of simple link assembly. Many studies discuss different types of air conditioning systems for buildings, such as in [19]. Liu et al. [20] emphasizes that modern control methods for HVAC systems are emerging, such as reinforcement learning (RL), and should be utilized in the future con- 
trol of these systems. Perng et al. [12] use a multi-objective particle swarm optimization to simultaneously enhance the ventilation performance while considering inlet size and outlet opening. The study uses an engineering simulation analysis system (ANSYS) tool to emulate the airborne speed and temperature dispersal inside a structure. The outcomes illustrate that the rooms could be cooled down by 2.9 and 1.7 degrees Celsius, respectively. Han et al. [21] studies the $S F_{6}$ gas dispersion characteristics using experimental and numerical methods in a substation building. The gas leakage angles are analyzed and diverse freshening strategy constraints are adopted, which include airborne passage plan, extent, and airborne-alternating frequency to assess airborne aeration function. Therefore, the results demonstrate that the gas escape angle can influence the concentration level in the room, thus requiring proper position and installation of the ventilation system. The study further emphasizes that there is severe worry in confined spaces such as battery rooms. Thinning ventilation is recognized as an active method to control and alleviate dangerous gas content in a crisis of unplanned escape. Nevertheless, intended for utmost aeration schemes used in business structures, deficiency exist for thorough strategy and optimum operating criterion. Brzezińska in [22,23] elaborates different tests that shows conditions which could occur in a battery room if ventilation fails. The study conducts experiments on a full-scale hydrogen emission to evaluate the release period and combustible haze creation based on presumed release speed. Hence, the results show that diverse aeration schemes create an energy storage system with attenuating effectiveness in hydrogen exclusion. Moreover, natural ventilation is effective as compared to mechanical systems.

The conventional proportional and integration (PI) control has inefficiencies which include the inability to deal with nonlinear systems, the gains are tuned for setting operating conditions of the HVAC system, and the control architecture is decentralized [24-26]. Consequently, proportional-integrate-derivative (PID) controllers focus on controlling the fan speed and fuel usage, and provide a weak rapid response to varying conditions [27]. Furthermore, Perekrest et al. [28] argue that, to effectively manage the heat supplied to rooms, it is important to determine the amount of heat energy needed for the room to maintain proper temperature conditions during varying times.

Qiang et al. [29] design and develop a connected assessing and isolated link expertise, which provides a connected assessment of temperature and moisture, as well as an interior space regulation scheme for peak power delivery room instantaneously. This is performed to improve the operating environment in the switch cabinets by condensing the humid air into water and discharge it outdoor. However, no results of the system performance are presented.

Therefore, based on the literature review, HVAC system network control panel design has not been extensively studied and has received little attention. Therefore, this research study fills this gap by designing an HVAC network control panel for a typical UPS battery storage room comprising LABs (i.e., valve-regulated (VRLA)). This design provides airborne to the room at an appropriate temperature for LABs. Because of the presence of gases such as hydrogen, oxygen, and electrical connections, the chamber is under a greater danger of flare-up/fire. This danger needs to stay reserved and hooked on the main attention through the initial strategy stage. Furthermore, it ensures that the airborne is provided at appropriate frequencies and temperatures to the battery room, such that vapors are removed and dispersed to the outside environment. It does this automatically and allows no human interface after all necessary settings and installation are completed. The control panel provides commands for closing and opening of dampers in the AHU, in case gases need to be extracted to the outside environments. This operation allows the fresh air to be absorbed from outside and regulates the battery room temperature at $25^{\circ} \mathrm{C}$ with a tolerance of $\pm 1{ }^{\circ} \mathrm{C}$. By providing this temperature regulation, it gives the best balance between battery capacity and lifespan. The network control panel of this type can be applied widely in the oil and gas industries, which requires their systems to comprise LonMark Certified profiles and meeting specification 0487. The wide application of this 
control includes heaters, rooftop units, and AHUs. This research is set to minimize the catastrophic events that could occur as stated in [3].

The paper is hereby organized as per the following scenarios: Section 2 discusses the state of the art analysis of the available literature, Section 3 explores the material and approaches utilized for the study, Section 4 elaborates outcomes and discussions of the study, and Section 5 concludes the findings on the design and implementation of the HVACS controller with the recommendations for future work.

\section{State of the Art Analysis}

This section discusses the related works available in the literature. Shah et al. [30] propose a sliding mode controller to provide a vigorous operating performance of AHU during disturbances. In this investigation, a PID controller has used a baseline for control performance indication. The results show that SMC outperforms the conventional PID control by evaluating variables which include tracking, diverse required temperature operation, and humidity. However, the study focuses on reducing energy consumption in building, thus improving the energy efficiency of the system. Liavoli et al. [31] propose a sub-optimal controller for the AHU that is grounded on SDRE with the pseudo linearisation display to develop both the observer and the control. The proposed controller is compared with the EKF observer. Hong and Kim [32] designs an MPC with the ability to be operated with data and predict the air supply temperature in AHU using a neural network. Furthermore, Kanak in [33] develops a temperature controller for an AHU using a typical available commercial device. The results show that the controller could maintain the desired temperature at $23^{\circ} \mathrm{C}$. Kurilla [34] proposes a model predictive control for temperature control in neighbor offices of an industrial building. The study emphasizes that, by incorporating network control panels/interface, it is possible to monitor the actual temperature of the room, required temperature set-points, and uncertainties from the opening of the doors and windows. It is further discussed that predictive controllers can remove human interaction with control parameters, thus enhancing energy efficiency. Gunay et al. [35] propose a procedure for determining the close to optimal sequence of operations applied to multiple zone AHUs based on optimization for building performance. The results of the study show that the system achieves an optimal supply of temperature at the desired setpoints. The temperature change varied from $16-20^{\circ} \mathrm{C}$ over the outdoor temperature of between $0-20{ }^{\circ} \mathrm{C}$. Besides, the proposed procedure shows an energy saving of approximately $20 \%$ when the AHU operates at constant temperature and when it has undergone preheating or precooling before actual use. Zhuang et al. [36] propose a torrent PID control to increase air temperature supply. The study uses external control loop for a temperature value setpoint by using a minimum air supply volume as a control target. Thus, the internal control loop manages air temperature supply by regulating the valve. However, the study applies the control method to a residential building. Besides, Gao et al. [37] propose a model-based torrent control to enhance the control robustness for the space temperature control of constant air volume conditioning systems. The space temperature regulation is achieved by controlling the water valve opening of the HVAC. A comparison in performance is performed between the convention PI and PID, and the results show that the torrent PI outperforms the conventional PI controller in terms of temperature dynamic regulation control and load tracking. Abdo-Allah et al. [38] emphasize that new generation of fuzzy logic controllers are utilized to manage the indoor temperature at desired levels, carbon dioxide concentration in AHUs, and speed of the fans. The study proposes to use FLC in regulating equal percentage optimal valves, fan speed, and the position of the damper in compliance with the exact hot water flow rate and air inside the building. Further, the study uses the FLC as an intelligent control to provide energy saving without compromising comfort levels. The outcomes of the study show that FLC outperforms the traditional PI controllers because it provides a stable response and withstands diverse parameter uncertainties. On another hand, because of the great focus on building energy savings without compromising thermal comfort, Oleolo et al. [39] use the system identification method to 
design a dynamic model for operating a centralized multi-circuit water cooled package unit of HVACS by controlling the temperature. Fiorentini et al. [40] propose the design, execution, and practical evaluation of a hybrid model predictive control for a solar-assisted HVACS that has on-site thermal energy generation and storage. The purpose of the control is to optimize the scheduling of the available thermal energy resources to adhere to comfort objectives. Whereas, Yang et al. [41] conduct a practical evaluation of MPC for HVACs that consist of dedicated outdoor air systems. This MPC is based on the linear state-space model to capture building thermal dynamics, thermal comfort, and building response predictions, as well as optimization. The multi-aim of the control cost function is applied to optimize energy utilization and thermal comfort. Afram and Janabi-Sharifi [42] propose an MPC grounded from the supervisory controller to shift the heating and cooling load of a residential building to off-peak hours to save energy. Consequently, the MPC produces the desired temperature set-points range for on/off controllers. The results of the study indicate that, when employing fluctuating temperature set-points, 16 percent of the cost is saved, unlike when employing a fixed temperature set-point of $25^{\circ} \mathrm{C}$. Erfani et al. [43] propose a nonlinear model predictive control to reduce the energy consumption of AHUs utilized in multi-zone areas and gas while maintaining the thermal comfort of occupants. To design the nonlinear model predictive control, the study utilizes a genetic algorithm (GA) and nonlinear autoregressive network with exogenous inputs. The results show that the nonlinear model predictive control could reduce gas and energy consumption of AHU and the deviation of temperature setpoints by $43 \%$ and $55 \%$, respectively. Raman et al. [44] propose a model predictive control that incorporates humidity and latent heat to reduce energy use and improve thermal comfort. The study compared a conventional MPC that does not consider humidity and the rule-based control of the proposed MPC. The results of the study show that the proposed MPC performs better than the conventional MPC and rule-based control. Berouinev et al. [45] evaluated the use of MPCs scheme for HVACs to enhance the indoor air quality at the same time as increasing the energy cost saving. The outcomes of the study show that MPC performs better than PI and state feedback controllers. Kurilla and Hubinský [46] propose a decoupled model predictive control to regulate the office temperature based on occupancy profile and disturbances. The results show that the decoupled MPC outperforms the conventional PID in terms of eliminating measurable disturbances.

Grygierek et al. [47] analyses various possibilities to limit high temperatures in a residential building by utilizing passive cooling. The investigation further proposes an optimized fuzzy logic controller to control mechanical ventilation. The optimization of the controller is achieved using the strength Pareto algorithm. The study emphasizes that the optimized FLC could enhance the thermal comfort of occupants during transitional climate change. Besides, if connected to the traditional cooling system, it may decrease cooling demand. Li and Wang et al. [48] elaborate that distributed sensing layouts and network control panels offer appropriate opportunities for distributed optimal control. The study proposes a multi-agent distributed method for the optimal control of multi-zone AHUs while considering indoor air quality and the use of energy. The results show that the proposed method is effective in getting a proper trade-off point between limiting indoor carbon dioxide concentration and reducing AHU energy utilization. Shah et al. [49] propose a lumped parameter model comprising a multi-zone variable air volume conditioning system to maintain the comfort level and reduce energy utilization, while sliding mode control is developed to ensure robust operation during unforeseen system disturbances. When the proposed control is compared with PID, the results show that the sliding mode controller is more energy-efficient than PID in regards to overshooting and settling time. Zhang [50] proposes a new PID controller grounded from predictive functional control which is evaluated on a chamber pressure of an industrial coke furnace. This controller is a combination of a PID with predictive functional control, which provides a simple structure of a PID. The results show that the proposed PID comprises better performance as compared to the conventional PID in terms of setpoint tracking and uncertainty rejection. 
However, the use of this control is limited only to the pressure coke furnace and not HVACs. Schito et al. [51] propose a multi-objective optimization method for HVACs in a museum to control the temperature and humidity for artworks, while not compromising the thermal comfort of visitors. He et al. [52] propose a control based on swarm intelligence to improve variable air volume air-conditioning system drawbacks, which include less expansibility, less universality, and high implementation cost. This control is distributed and flat. It comprises a fundamental unit, communication network, calculation, and an algorithm. Ning and Zaheeruddin [53] propose a neural network model grounded adaptive control for variable air volume HVAC and refrigeration to obtain great temperature setpoint tracking control, released air temperature, chilled water supply temperature, and static pressure. The NN and automatic tuning is used to update the PI controller gains online. The outcome of the study shows that adaptive PI control provide faster response and minimum overshoot, as compared to the traditional PI control. Mohammed Ali [54] proposes intelligent control for HVAC to provide optimum temperature setpoint and relative humidity. Wang et al. [55] propose a combination of an iBeacon-enabled indoor positioning system with VAV-HVAC to optimize system control and save energy grounded on high-resolution occupancy detection. Bay et al. [56] propose a predictive steady-state optimal control to reduce economic costs linked with operating a building. It is because the necessity of energy efficiency, occupant health, and thermal comfort is on the rise. Some studies, such as in [57-59], focus on energy savings and lack control of temperature evaluation in battery rooms. Despite the state-of-the-art analysis of the available literature, the study focus is mainly on the residential building which includes offices. It is noticed that literature based on substation battery room temperature control and network control panels is scarce. Thus, it is the purpose of this paper to fill this gap in the literature by providing this investigation. Moreover, although different controllers are introduced and implemented, the PID controllers still dominate the position with advantages such as simple structure, ease of implementation, and strong robustness. Besides, it has strong compatibility because it can be integrated with some of the available advanced numerical algorithms to search for more superior control performance and thus better temperature control of HVAC system [60].

\section{Materials and Methods}

The HVAC network regulator board is fitted to regulate an air-handling unit, thus ensuring that the temperature inside the battery storage chamber remains reserved constantly at $25^{\circ} \mathrm{C}$ and within a \pm 1 degree Celsius tolerance. The utilized airborne aimed at airing battery chambers should not surpass 26 degrees Celsius. However, according to the specification used by the electric utility supply Eskom, the HVAC system installed in the battery chamber has to be separated away from the entire HVAC system available in the building. Besides, an airflow device that is situated crosswise all fans need to have the ability to assess separately installed fans. These sensors should possess a least of Ex _evaluated or under the inherent protection (I.S) loop [61]. Consequently, the IEEE standard 1634-2018/ ASHRAE E-Guideline 21-2018 stipulates that the inherent protection wall unit should be utilized to defend the unit straddling in a dangerous site. The barrier module separates the unit straddling in a dangerous zone, thus keeping the unit benign. Wholly apparatuses inside the battery chamber, which include temperature device for the exhaust, fan of the exhaust, airflow switch, and bound switch for the fire damper that remain fitted to the side of the exhaust, must incorporate the inherent safety ring. This is because the battery chamber is regarded as a dangerous zone. Therefore, the damper of the actuator has to be accepted earlier. It needs approval under ATEX Exd_rating. Once the flow switch is approved under Exd_rating from the plant, its utilization in a building can resume. However, nonapproved units can be integrated with an intrinsic barrier device. An extracting fan would continually operate to reduce the gas concentration inside the chamber. Besides, the study does not consider natural ventilation systems because of 
their inefficiencies during uncertain weather conditions. Therefore, forced ventilation is adopted [62].

Liavoli and Fakharian [63] offer a state-reliant-on optimum regulator grounded on virtual linearization and state-reliant on Riccati equivalence (SDRE) to accommodate the complex dynamic model of the HVAC. This is because of the nonlinear and complex nature of integrating AHU variables. The neutral Kalman filter (UKF) grounded upon climbed neutral alteration (SUT) is proposed to provide a state estimation of AHU that is controlled through a linear quadratic regulator. The filter attains greater precision when utilizing a climbed neutral alteration (UT). It utilizes sigma arguments and applies no linearization to yield reduced mistakes, thus conserving the fluctuating scheme features [64]. Yuan et al. [65] propose an original switched adjustable regulation approach for the AHU. The outcome of the study shows that the approach has fewer computational difficulties and can resolve drawbacks of fluctuating inputs to the system. The control realizes improved constancy and decent operating performance through linearizing the oscillatory changing aspects regarding distinct operating styles. Ionesi and Jouffroy [66] use an adjustable rule through an anti-windup regulator and a transferring rule that is recognized based on abide period. These rules are applied to reduce disturbances of the transferred scheme during operation. The study uses a practical approach to assess the operational performance of the controlling role procedure, which provides confident outcomes. This controlling role practice generates a scheme of direct equivalences via burgeoning the fluctuating inputs of the signals with an identified constantly. Zou et al. [15] propose other techniques, which include long short-term memory (LSTM), neural networks, and profound reinforcement learning (DRL). This paper adopts a typical range of controllers, which have a thirty loop PID control because the system operator selects the operational requirements grounded upon knowledge of the building supervisors, and the supervisor's understanding of the used system.

To ensure proper ventilation control, the hydrogen concentration in a battery room should be below $4 \%$ as its lower explosive level (LEL). The ventilation consists of both mechanical and natural systems [22,23]. The power supply is usually utilized to convey dimensions of an alteration of a regulated state after the regulator. This is to convey these measurements to additional portions of the scheme and to interpret the alteration operation by the last regulator part. The sensing element signals established after could be utilized to yield unique or a mixture of electro-mechanical yields. Meant for instance, numerous actuators remain regulated by one regulator. Sole regulated actuator mixtures remain probable deprived of essentials aimed at the key airborne supply, similar to that in inflatable regulation.

The HVAC system should accommodate the various battery-operating modes, which include accelerated charge or recharge, discharge, bulk charge, float charge, accelerated/boost/equalize charge. The most important element for designing an appropriate environment for stationary batteries is that the current, hydrogen release, and heat generation values need to be attained from the manufacturer. Nevertheless, these values could not be obtained from the manufacturer. Therefore, Equations (1) through (10) give reasonable upper constraints estimations for different operating modes. Besides, they are based on assumptions that they apply to the broadest range of batteries. Yet, the hydrogen generation and heat generated are determined by assuming that valve-regulated lead-acid batteries (VRLABs) with low-antimony absorbed glass mat (AGM) are used for the application, and Equations (1) through to (10) are used as stated in [62]:

$$
H_{2-\text { rate }}=n_{\mathcal{c}} \times C_{8} \times 2.69 \times 10^{-11}
$$

where $n_{c}$ is the number of cells in the room and $C_{8}$ is the 8-h ampere rating of a lead-acid cell to $1.75 \mathrm{~V}$ at $25^{\circ} \mathrm{C}$.

$$
q_{w}=0.34 \times I \times n_{c}
$$


where $q_{w}$ is the total heat generated in watts and $I$ is the current through each string in amperes.

Therefore, for the accelerated charge operating mode, Equations (3) and (4) are used to determine the hydrogen and heat generation:

$$
\begin{aligned}
H_{2-\text { rate }} & =n_{c} \times C_{8} \times 5.36 \times 10^{-11} \\
q_{w} & =0.449 \times I \times n_{c} \times t
\end{aligned}
$$

where $I=C_{8} \times 0.0130$.

During discharge mode, batteries deliver power to the load and can last for hours. Thus, during this mode, particularly for the UPS, a high rate discharge pattern takes place. Therefore, only heat generation is associated with this mode and is determined as in Equation (5):

$$
q_{w h}=\left(I \times t \times n_{c}\right) \times\left((0.727 \times(s . g .))+0.0718-\frac{V_{c-e n d}}{2}\right)
$$

where $I=\frac{I_{L}}{N_{s}}, N_{S}$ is the number of parallel strings supplying the load, $I_{L}$ is the load current, s.g. is the nominal specific gravity of the fully charged cell, and $V_{c-e n d}$ is the average expected end-of-discharge voltage per cell in the battery room.

It is worth noting that, during the bulk re-charge mode, there are no gases and only heat is generated. Equation (6) represents the heat generated during the re-charge mode. This is because the re-charge is highly controlled by the battery charge set limits. However, during the initial and refreshing charge mode, this mode occurs once during battery lifespan, and ventilation design is not necessary for this mode of battery operation.

$$
q_{w h}=C_{r-s} \times n_{c} \times 0.138
$$

where $C_{r-s}$ is the ampere-hour (Ah) removed from the battery string during the discharge period.

The failure mode is one condition that can occur during battery operation, which can include thermal runaway, shorted cells, cell reversal, and charger runaway. During thermal runaway, high currents are drawn through the battery in float or equalize mode, thus increasing gassing. This phenomenon can be detected by battery temperatures that are higher than ambient. Therefore, the generated heat and hydrogen during thermal runaway can be determined as in Equations (7) and (8):

$$
\begin{gathered}
q_{w h}=0.455 \times I \times n_{\mathcal{c}} \\
H_{2-\text { rate }}=n_{c} \times C_{8} \times 6.28 \times 10^{-10}
\end{gathered}
$$

where $I=C_{8} \times 0.0257$.

Although cell reversal is an extremely rare case to occur in battery rooms, theoretically one or two cells could undergo reversal during discharge. Hence, it is important to determine the heat and hydrogen rate that can be emitted during this condition using Equations (9) and (10). Furthermore, toxic hydrogen sulfide gas is possible.

$$
\begin{gathered}
q_{w}=3.28 \times I \times n_{c} \\
H_{2-\text { rate }}=1.27 \times 10^{-7} \times I \times n_{c}
\end{gathered}
$$

where $I=\frac{I_{c t-\text { spare }}}{N_{s}}, I_{c t \text {-spare }}=\left(\sum_{c=1}^{n} I_{c}\right)-I_{L}, I_{c t \text {-spare }}$ is the maximum spare charging capacity available to charge the battery, $I_{C}$ is the capacity (ampere) of the individual charger, and $I_{L}$ is the average parallel load current over a given period.

The regulator board (NCP) contains double portions, as shown by Figure 1, namely:

1.1. Control of usual actions for complete items that are resident of the battery chamber or zone somewhere an NCP is situated through the software. 
1.2. Critical control (hard-wired), which includes manual start, stop and fire signal; the second one is regarded as the serious regulation, which regulates entirely the usual operation, and fire situation. These are wholly hard-wired in the board.

The trail classification of actions adopted through the cause-and-effect milieu, as shown in Table 3. The NCP forms a share of the structural organization scheme, nevertheless remain located nearby the plant housings or zones wherever the components stay regulated. Roughly, these electrical regulators entail valve actuators, temperature, pressure, and moisture regulators with dedicated relays, motor-starters, and contactors. These regulators remain power-driven through little potential, which depends on the electrical circuit necessities. Regulators may be electrically connected to achieve any prime or bounded purposes (i.e., peak/little boundary). Electrical actuators can either be a spiral or non-spiral reoccurrence. Here, in this case, the controllers are hard-wired to perform primary functions and electric actuators are spring return.

Table 1 describes the specification of the proposed network control panel, as illustrated in Figure 1.

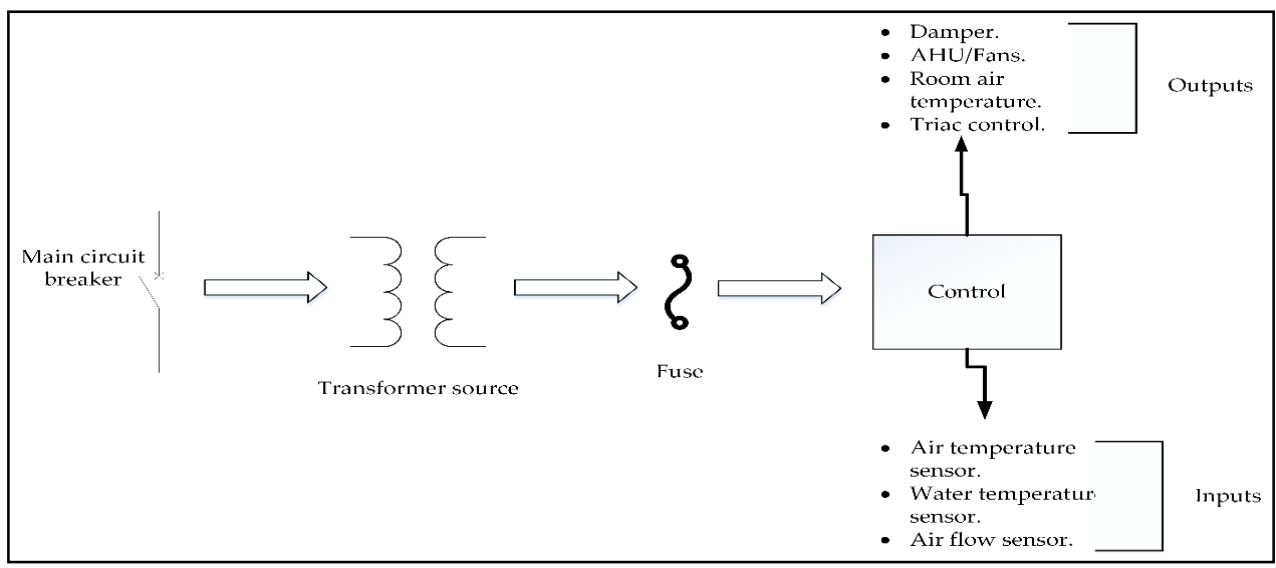

Figure 1. Proposed network control panel.

Table 1. Product description specification for the network control panel as proposed.

\begin{tabular}{cccc}
\hline Item No. & Description & Size & Manufacturer \\
\hline 1. & $\begin{array}{c}\text { Miniature circuit } \\
\text { breaker }\end{array}$ & 2-Ampere, C-curve & General Electric. \\
\hline 2. & Transformer & 220 V/24 V-AC, 100 VA & DF Electric. \\
\hline 3. & Fuse & 4-Ampere rated & DF Electric. \\
\hline 4. & Controller & 24 VAC/DC, ECL300, 600, and ECx420 & Distech Controls \\
\hline 5. & Damper actuator & 24 VAC, input voltage 0-10VDC & AXIO \\
\hline 6. & Temperature sensor & Thermocouple probe Tk-100 & VCP \\
\hline 7. & Airflow switch & - & VCP \\
\hline
\end{tabular}

\subsection{Control Panel Equipment}

These specific varieties of regulators are grounded upon typical microchips programmable regulators that are intended to regulate diverse structure computerised operations, which include AHUs, coolers, reservoir thrust, chilling towers, etc. This range, which is one type of these controller, is a dense and entrenched regulator under a server stage. The controller wrenches the joined terminals that are collected. For example, the regulator, administration, data acquisition, alarms, arrangement, and link supervision purposes employing internet connection, as well as web-based helping abilities within a minor, dense stage. An intrinsic safety block unit is utilized to guard the units straddling in dangerous sites. Therefore, entire apparatuses, which include exhaust temperature 
instrument, a fan of the exhaust, airflow switch, and boundary switch for fire valve that remain connected to the exhaust adjacent to the battery chamber, must be a portion of the I.S circle. These create the regulator board of the battery chamber to be meek and easy to implement and install, because all the components mentioned can be connected into one system for condition monitoring purposes. In normal buildings, the intrinsic safety barricade unit is not applied because areas are not denoted as dangerous. Hence, if the apparatuses are not within the intrinsic safety ring, they can harm these instruments then the whole regulator board.

\subsection{The Usual Process of an AHU through Interior Space Heating System and External Air Source through the Valve}

In terms of routine check-ups, for wholly AHU valves and fire valves, a scheduled examination is undertaken to assess the valves for any malfunctioning with the actuator/dampers themselves. During these scheduled tests, the HVAC is triggered, and entire AHUs, situated somewhere in the valves, will remain to a stop. After these tests, all systems will come back to usual working situations after the examination is disabled. During the fire incident, an indicator from the battery supervision scheme triggers the unit inside the perilous regulation, which holds a fire state. Once the fire indicator is triggered, the serious regulator, which is hard-wired, will halt the wholly usual functioning of entire AHUs and fans that are providing the zone. Furthermore, it will stop all operations where the fire incident is located and shut down wholly AHU valves and fire valves to suppress the fire inside that region. After the emergency fire personnel has ensured that the area is safe, the smoke from the fire needs to be removed from the zone. Then, all AHU heaters will be switched on to operate. It needs to reach a certain heat $\left( \pm 25 \pm 1^{\circ} \mathrm{C}\right)$ in a chamber, because the system may fail to reach the required heat/temperature when the water flow is still. It is for these reasons to dodge partaking the warmer being switched on and cooled water mixing concurrently. Even when the warmer is imaginarily meant to start up, and in case there is no airflow, it will not be switched on because the warmth will accrue significantly inside the unit and damage some devices. The considered AHU design is based on Equation (11), as described in [27].

$$
\frac{d u}{d t}=Q_{\text {loss }}+Q_{\text {gain }}
$$

where $Q_{\text {loss }}$ is the warmth allocation from the chamber to the outdoor, $Q_{\text {gain }}$ is the warmth allocation from the warmer to the chamber, $d u$ is the internal heat, and $d t$ is the change in time.

These range of controller applies a fuzzy inference system (FIS) algorithm to switch the heater on/off at set temperature requirements, as stated in [62], which state that the temperature should be $25^{\circ} \mathrm{C}$ with a $\pm 1^{\circ} \mathrm{C}$ tolerance.

\subsection{Design of the Main Controller}

Existing literature report intelligent control methods, which include model predictive control (MPC), gain scheduling, optimal control, robust control, nonlinear adaptive control, fuzzy logic, genetic algorithm, etc., [32,34,35,38,40-48,51-53,56-59,67-84]. As compared with PIDs as proposed in this study via mixing loops, they are robust and energy efficient. However, they have drawbacks, which include the requirement of centralised operation with a heavy burden for sensing, communication, and computation, thus leading to higher implementation cost as compared to on/off PID control [85]. Figure 2 shows the room temperature regulation algorithm that is programmed on this range of the controllers. The local level PID controller mixing loops are implemented to regulate the battery room temperature set-point [86]. 


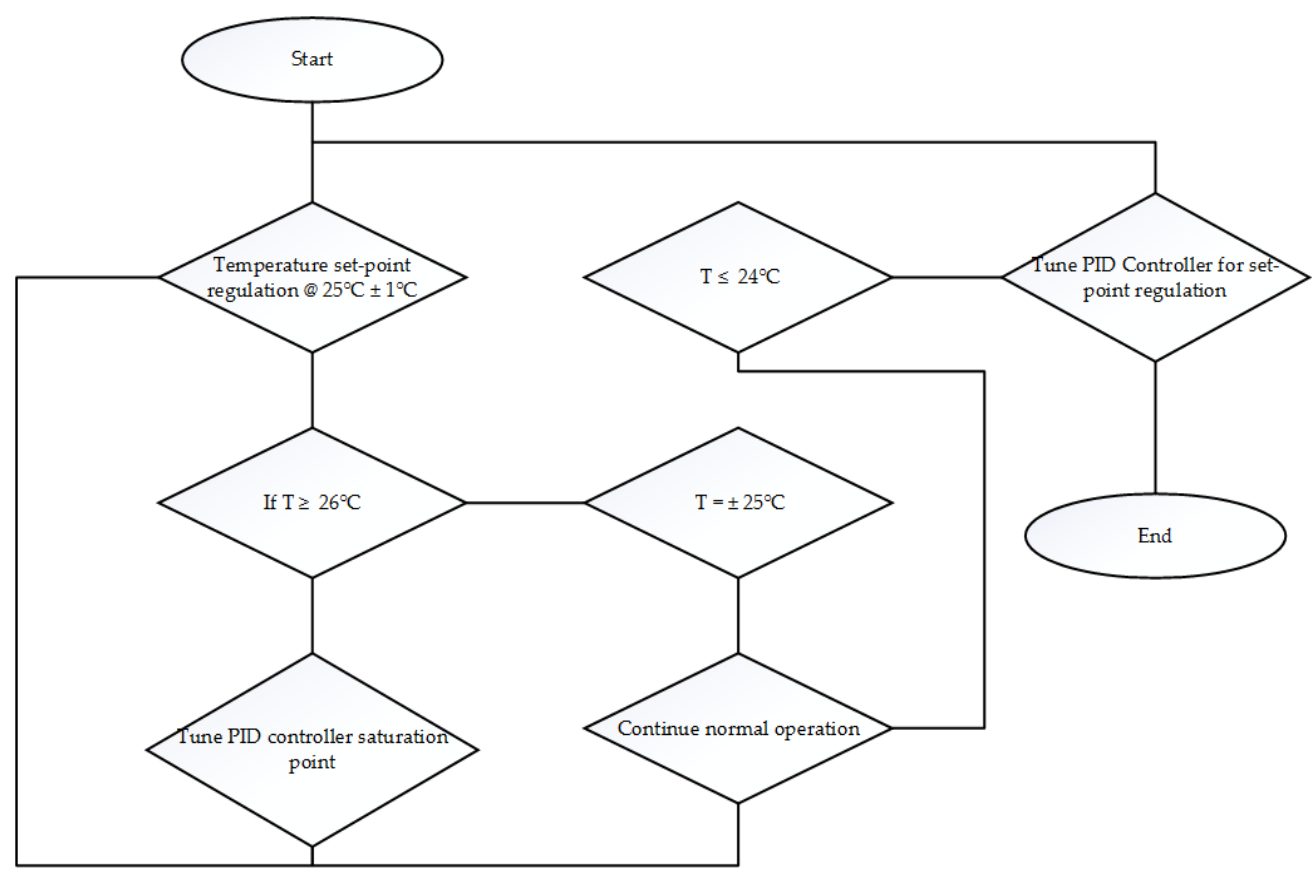

Figure 2. Set-point temperature control algorithm for a battery room.

\subsection{Hardware, Software Design, and Field Control Equipment}

The system may be custom automated employing EC-gfxProgram over any ECNet $^{\mathrm{AX} \text { TM }}$ Pro. The EC-Net ${ }^{\mathrm{AX} \text { TM }}$ Pro is excited through Niagara ${ }^{\mathrm{AX}}$ Framework $^{\circledR}$ or LNS $^{\circledR}{ }^{\circledR}$ based software, such as Distech Controls' Lonwatcher 3. The software creates an easy interface to quickly create an individual control sequence that can meet many specifications for AHUs. The control display allows the operator to have immediate access to internal controller data. The typical system comprises with wall unit profile, hardwired gas detection profile, hardwired fire alarm profile, hardwired full ventilation profile, hardwired full recirculation profile, hardwired safety instrumented system, ten universal inputs, and eight universal outputs. These inputs and outputs control a wide range of HVAC equipment. The controllers embedded in this system can operate employing a variety of instruments, especially those that are recommended by Allure ${ }^{\mathrm{TM}}$ EC-Smart-Vue type of interactive chamber instruments. These sensors are used for indoor temperature measurements, setpoint adjustments, fan-speed choice, and condition supersede. Moreover, these regulators are prepared with exposed wireless communication. Hence, Figure 3 shows the hardware connection of the system [87].

In terms of airborne discrepancy compression switches, these discrepancy compression switches remain appropriate for little discrepancy of compression transferring use in HVACs for showing fan states/murky filter. In terms of the channel moisture and temperature source, the canal moisture and temperature source (HDTT) measures the comparative moisture and temperature of the airborne canal using a temperature instrument. The canal temperature instrument (TDSH) is uutilized for detecting the airborne temperature in HVACs (for example, it supplies airborne and removes toxic air to the outside). In terms of involvement of temperature devices, these TISB/TIS devices are utilised for obtaining the temperature of the fluid or gassy media (e.g., space heating aquatic) in HVACs. Chamber moisture and temperature source quantify the comparative moisture and temperature of the airborne. As for spring-return actuator, various actuators are used for adjusting dampers with safety functions on all fire dampers and dampers on the air-handling units. The fire damper for this design is different because the damper is located inside the battery storage room, thus the damper must be I.S rated from factory rotary actuator. Various rotary actuators have seen wide applications in butterfly valves and on the piping installation for control of the shut-off valves. The modulating valve actuator is used for three-way valves 
on the piping installations, varying from $0-100 \%$. The triac control heat module controller receives a signal of $0-10 \mathrm{Vdc}$ from the controller and outputs power to heater elements. It comes in different heating capacities $(\mathrm{kW})$. Proper control of pressure and temperature can ensure improved comfort, energy, and monetary savings in HVACs because HVACs provide a healthy indoor environment for the safe operation of the equipment it serves. Besides, temperature setpoints are directly linked with the energy use of the HVAC. Mixing loops could be used to meet the required different pressure and thermal power amongst consumers to enhance performance and energy efficiency [25].

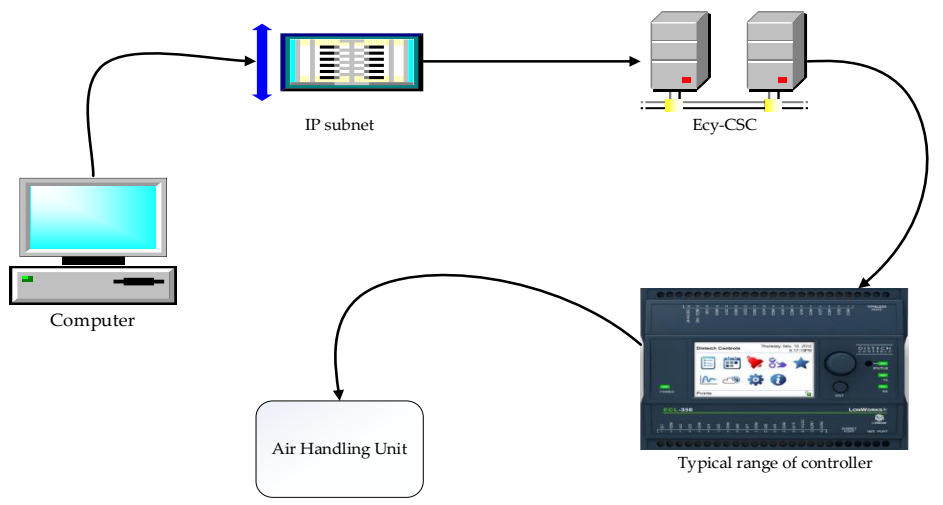

Figure 3. System demonstration during programming for AHU.

Table 2 below describes the specification of the system demonstrated in Figure 3.

Table 2. System integration specification.

\begin{tabular}{cr}
\hline Item No. & Description \\
\hline 1. & Lenovo Laptop (Windows 10, 64-bit operating system). \\
\hline 2. & IP subnet for connecting multiple ECY devices for multi-application purposes. \\
\hline 3. & ECY-PTU-107/ECY-PTU-207/ECY-PTU-208 terminal unit controller. \\
\hline 4. & ECL-300 and ECL-600 (Distech Controls). \\
\hline 5. & HVAC-220VAC System. \\
\hline
\end{tabular}

In terms of the software, the operational sequence adopts the following steps:

- The controller sends an output signal to open the AHU dampers.

- The controller receives an input signal that is relevant to the AHU dampers and allows the dampers to open.

- Additionally, the controller receives an input signal that is relevant to the AHU fire dampers and allows the dampers to open.

- Then, the controller sends an output signal to startup the fan.

- After $120 \mathrm{~s}$, and after the fan or AHU is commanded to startup, the controller receives airflow feedback, and the fan status is set to "run mode".

- Heating and cooling are controlled by a single PID loop. This is to avoid simultaneous heating and cooling operation from the AHU.

- Thus, a weekly damper test is conducted two hours before the AHU/fan lead/lag (ie. Run/standby operation) changeover is carried out using a scheduler.

In terms of general and critical alarm functions, there is no changeover operation of the AHU fan with the general alarm when it is active; however, it needs to be attended to for effective operation. Secondly, the AHU/fan undergoes general alarm settings if the following conditions are not met, which include damper failing a weekly test, and if the AHU fan is commanded to stop (OUTPUT OFF) and the airflow status reflects "flow", and an alarm is generated. The fan has to be stopped manually. 
The critical alarm, when it is active/ring, forces change in the operation of the AHU fan to a standby AHU fan. Once the critical alarm is cleared, the operation will be reverted to before the alarm occurred (original lead unit resumes operation). The AHU fan should undergo critical alarm when the following conditions are met: (i) if the AHU/fan motor overload is tripped; (ii) if the fan start command is active and no airflow is detected or the fan motor running status is not received after $120 \mathrm{~s}$ (the AND logic gate is used to achieve this goal); (iii) if heating safeties generate an alarm and disable heating automatic reset overheat status; (iv) if there is manual reset overheat status (Trips the isolator/circuit breaker); and ( $\mathrm{v}$ ) if there is a triac alarm.

\section{Results}

This section discusses the results of the tested product. The board is verified at the plant employing fans and a logic valve with a cause-and-effect matrix, as shown in Table 3. A fan and a valve cause-and-effect matrix is a process relating to what way fans and dampers must function in a usual and fire incident. Due to not connecting practical apparatuses once the board is verified at the plant, the study uses a $24-\mathrm{V}$ alternating current pilot light to emulate the operation of a damper and a fan. When the pilot light is OFF, it describes that the fan is OFF. When the light is ON, it describes that the fan is ON. Therefore, wholly valves are a spring-return source, whereas exhaust air valves are spring-open, hence, they require a $24-\mathrm{V}$ alternating current source to operate and close. The fire valve is spring-closed, thus it requires a $24-\mathrm{V}$ alternating current source to be operated in an open state. Point-point checks are conducted employing a volt-meter to guarantee steadiness and precise wire configuration. The shielding apparatuses, which include fuses and circuit breakers, are verified for precise operation. A link portion is utilised as a fire indication.

Table 3. Tested control panel.

\begin{tabular}{ccc}
\hline & Results of the Tested Control Panel & \\
\hline Description & Under Normal Conditions & Effect \\
\hline Supply fan A & Label & Run/Standby \\
Supply fan B & AHU1A & Run/Standby \\
Supply damper for AHU1A & AHU1B & Open/Close \\
Supply damper for AHU1B & SAD1A & Open/Close \\
Fire damper 1 & SAD1B & Open \\
Exhaust damper A & FD1 & Open/Close \\
Exhaust damper B & EAD5A & Open/Close \\
Exhaust fan A & EAD5B & Run/Standby \\
Exhaust fan B & FC1A & Run/Standby \\
& FC1B & Off \\
Supply fan A & In the Fire Event & Off \\
Supply fan B & AHU1A & Open/Close \\
Supply damper for AHU1A & AHU1B & Open/Close \\
Supply damper for AHU1B & SAD1A & Closed \\
Fire damper 1 & SAD1B & Open/Close \\
Exhaust damper A & FD1 & Open/Close \\
Exhaust damper B & EAD5A & Run/Standby \\
Exhaust fan A & EAD5B & Run/Standby \\
Exhaust fan B & FC1A &
\end{tabular}

\subsection{Testing Procedure}

The below phases are tracked to test the regulator board:

- An electrical schematic utilised to develop the system is appropriate.

- A regulator board must be switched off beforehand.

- Wholly apparatus utilised are appropriate. 
- The colour selection of the cables is verified to authorise that they are precise. The regulator board is connected as per the illustration: developed arrangement ties with the diagram. The fuse and circuit breaker magnitudes are as per the illustration.

- Cable indicators and additional apparatuses tags are developed as per the diagram. Checked for no wobbly contacts. Checked if the gland bowl, entrance, and transformers are earthed correctly.

- The regulator board is switched on and examined for precise operation employing the cause-and-effect matrix.

\subsection{Tested Product Results}

Table 3 displays outcomes of the tested product found once the board has been verified under usual situations. Some fans function as operating and reserve; individual fans may operate while the damper of the running fan is exposed, and while the damper is OFF and the fan is locked. The fans remain connected in equivalent because if the other one is operating; the extra fan should be OFF. Therefore, the valve closes to dodge the airborne from recurring. A fire damper (FD1) is exposed to permit the airborne to stream into the battery chamber. During fire incidents, the power supply is broken upon in cooperation of the source fans; when one fan is operational to evade dispersal of fire, their associated valves will not be necessary whether they are closed/opened, then FD1 will continuously be locked. The exhaust fans will remain operational to remove gases.

Table 3 summarizes the outcome of the study obtained when the panel is verified during usual situations. Roughly, fans function following operationality and reserve conditions, and one fan can operate at a period. The fan that is operating its valve is opened, and for the other fan that is off, its valve is locked. Furthermore, Figure 4 illustrates the operation of the system, which is summarised in a tabular format of Table 3 as indicated. The outcome of the verified regulator board and the AHU system is related to the specification, illustrated by Table 4 . The board installation and programming are accomplished effectively. The temperature of the battery chamber is well-regulated within the prescribed constraints, and the dangerous gases are extracted to the outside environment. All the system requirements are achieved as per the specification. Wholly deviations of the unique strategy are completed and suggestions include that field apparatuses must be bought upfront.

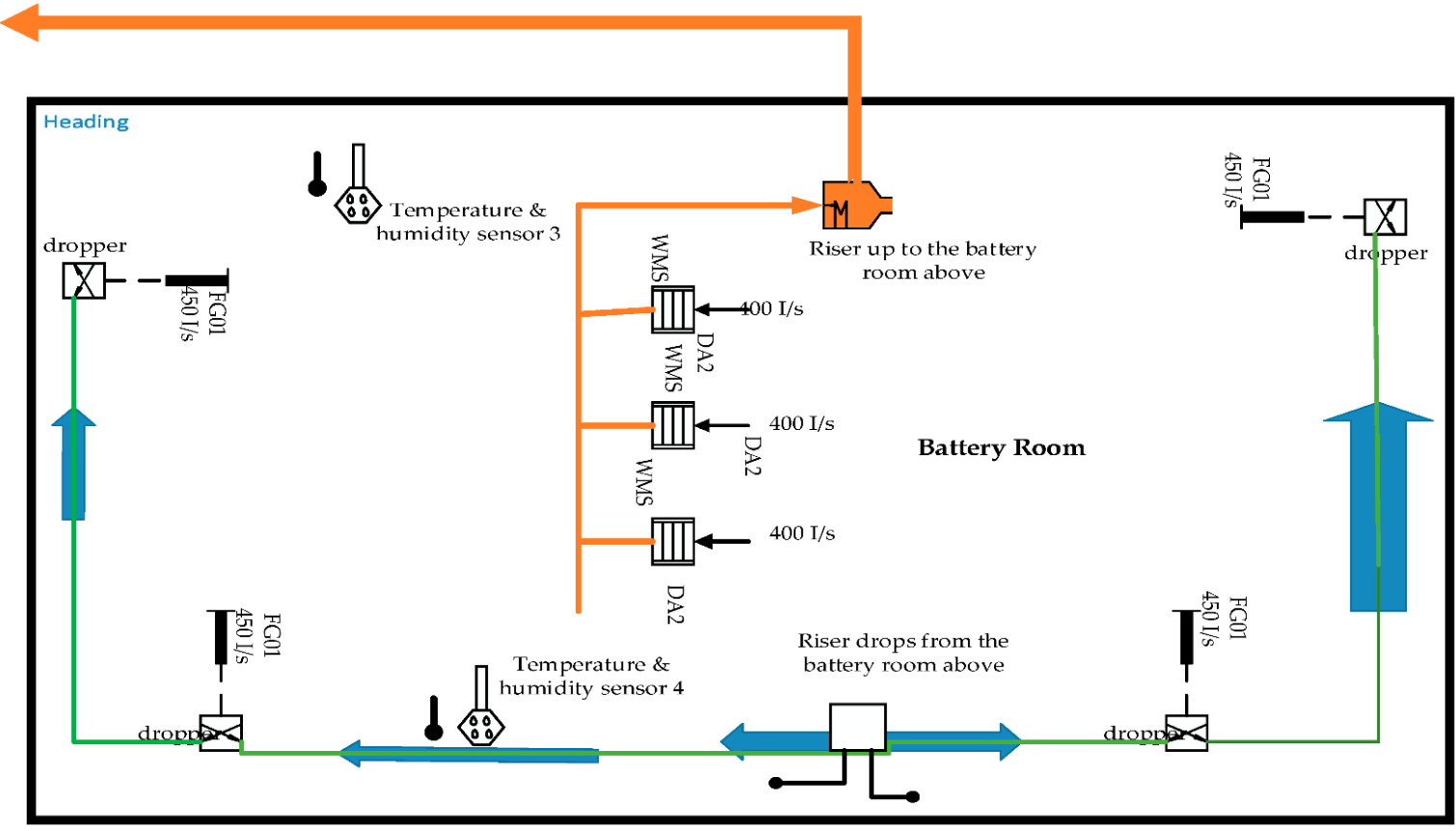

Figure 4. Results visual demonstration of the battery room. 
Table 4. Comparison of the tested product results against the requirements.

\begin{tabular}{|c|c|c|c|c|}
\hline \multicolumn{5}{|c|}{ Under Normal Conditions } \\
\hline \multicolumn{3}{|c|}{ Results of the Tested Product } & \multicolumn{2}{|c|}{ According to Requirements } \\
\hline Description & Label & Effect & Similar/Different & Status \\
\hline Supply fan A & AHU1A & Run/Standby & similar & Correct \\
\hline Supply fan B & AHU1B & Run/Standby & similar & Correct \\
\hline Supply damper for AHU1A & SAD1A & Open/Close & similar & Correct \\
\hline Supply damper for AHU1B & SAD1B & Open/Close & similar & Correct \\
\hline Fire damper 1 & FD1 & Open & similar & Correct \\
\hline Exhaust damper A & EAD5A & Open/Close & similar & Correct \\
\hline Exhaust damper B & EAD5B & Open/Close & similar & Correct \\
\hline Exhaust fan A & FC1A & Run/Standby & similar & Correct \\
\hline Exhaust fan B & FC1B & Run/Standby & similar & Correct \\
\hline \multicolumn{5}{|c|}{ In the Event of a Fire } \\
\hline Supply fan A & AHU1A & Off & similar & Correct \\
\hline Supply fan B & AHU1B & Off & similar & Correct \\
\hline Supply damper for AHU1A & SAD1A & Open/Close & similar & Correct \\
\hline Supply damper for AHU1B & SAD1B & Open/Close & similar & Correct \\
\hline Fire damper 1 & FD1 & Closed & similar & Correct \\
\hline Exhaust damper A & EAD5A & Open/Close & similar & Correct \\
\hline Exhaust damper B & EAD5B & Open/Close & similar & Correct \\
\hline Exhaust fan A & FC1A & Run/Standby & similar & Correct \\
\hline Exhaust fan B & FC1B & Run/Standby & similar & Correct \\
\hline
\end{tabular}

Therefore, Figure 4 below shows the visual illustration of the above-tabulated results. It shows that the air from the battery room is extracted to the outside environment as indicated by the orange line. The two dampers located in the battery room (namely FAD1A and FAD1B) are not part of the control. Therefore, they are manually adjusted to provide $100 \%$ of fresh air to the battery room. The extracted air from the battery room is represented by the orange line which extracts the air to the outside environment through a damper. However, the damper is in an open state all the time because it is not required to operate.

In Figure 5, the AHU is situated on the first floor of the building. The exhaust fans are also located on the first floor. These exhaust fans extract the air and gases from the battery room, which is located on the ground floor of the building to the outside environment. Exhaust air and gases pass through the first floor when they are extracted to the atmosphere, as shown by the orange line (the orange line in Figure 4 is the same line as in Figure 5). The supply duct, which is represented by the blue line, drops down to the battery room. The duct connects through the fire damper (FD1). Then, the duct splits into two different directions as indicated in Figure 4. Hence, it supplies the battery room with the desired air temperature and ensures that a required level of humidity is achieved within the set limit. DA3 in Figure 5 is a mechanical damper, which brings in fresh air from the outside environment. Thus, all the connected types of equipment are located on the first floor of the building, including the NCP.

Furthermore, the fresh air damper becomes locked in a fully open state condition. Under normal AHU operation, one of the AHU is run, and its supply damper opens while the other AHU is off and its damper closed. The supply fire damper (FD1) will open to all conditioned air to flow into the battery room (i.e., blue line shows fresh air direction). On the contrary, one exhaust fan has to run, and its damper must be open while the other fan is off and its damper is closed. Then, the gases can be extracted to the outside environment. Under the fire event, both AHUs must stop and their damper must be closed. One of the exhaust fans must continue the operation, although there is a risk of fire in the battery room. 


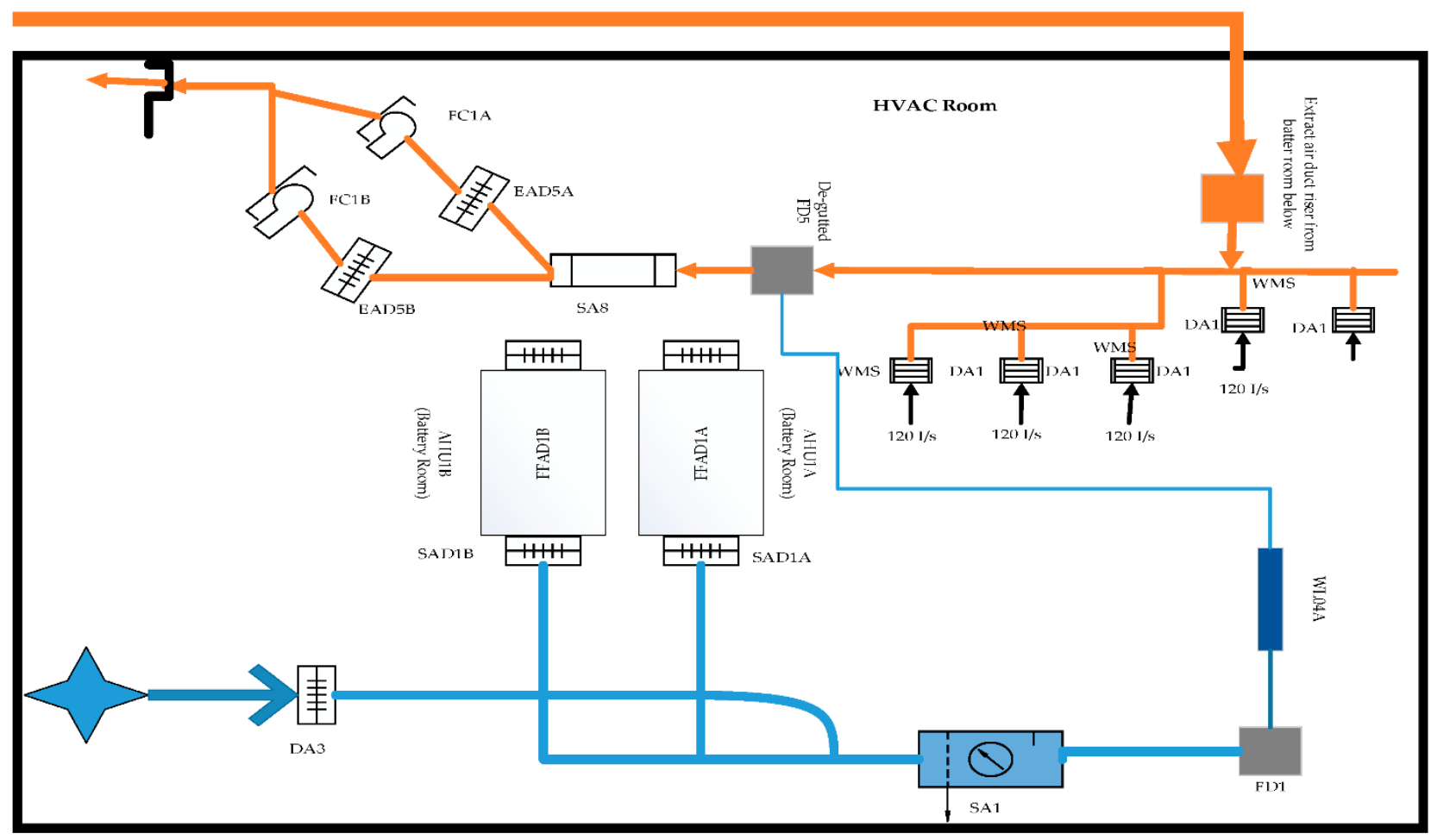

Figure 5. Results visual demonstration of the HVAC room and its components.

\section{Conclusions and Recommendations}

In the study, an HVAC network control panel is designed and implemented for the safety enhancement of the UPS battery storage housing room. This is achieved by using a specific range of controllers, which have more than thirty loops of proportional, integral, and derivative (PID) control to achieve a cost-effective design. It performs the required function of extracting hydrogen and oxygen, and maintaining the desired temperature of the battery storage room within recommended limits (i.e., $25 \pm 1{ }^{\circ} \mathrm{C}$ tolerance) without compromising quality, as set out in the user requirement specification in Appendix A. The area temperature is controlled by regulating a damper position based on the temperature setpoints. The heating, ventilation, and air conditioning system regulator board confirms that no return of air exists inside the battery chamber to the AHU. The zone temperature is controlled by adjusting the damper position according to the temperature setpoint. Two fans exist on the exhaust side of the battery room to extract the gases from the battery room. These fans, used for the exhaustion of the battery chamber, operate continuously and interchangeably, leading to no interruptions of fans operation. The whole of the battery chamber's perilous alarms is directed to the controller counter. These critical alarms include parameters for sensing extreme hydrogen and oxygen gases in the room as well as parameters of temperature deviations from the set temperature value of $25^{\circ} \mathrm{C}$ with a tolerance of $\pm 1^{\circ} \mathrm{C}$. All safety alarms and indicators of this controller are fail-safes; therefore, when sensing failed apparatus, the alarm triggers through indicators, namely. no airflow, actual great or little temperature, and burn recognition. The designed network control panel operates successfully as required, according to the user requirement specification. The results indicate that HVAC control consistency and steadiness are very important because small scheme failure could result in high energy consumption and temperature distress in the battery room. Besides, an improved controller could enhance energy and price by developing the efficacy of the HVAC scheme. Therefore, the study contributes to the body of knowledge in controlling extreme hydrogen and oxygen gases in UPS battery chambers, as well as controlling the acceptable temperature limits for safe operation. Hence, it maintains the battery room temperature within $25^{\circ} \mathrm{C}$ and ensures that the humidity level 
is within the acceptable limits. This approach also enhances the performance as well as the lifespan of batteries. The system control panel allows the user to access control parameters, such as changing temperature set-points, fan speed, sensor database, etc. This accessibility is necessary to ensure that poor control performance of the system is avoided at all costs. Poor control of HVACs could lead to discomfort, and in some instances, it can damage electrical equipment. The hardware is configured to detect and extract extreme hydrogen and oxygen gas content in the battery room to the outside environment through HVACS. Besides, the software of the controller ensures that the AHU dampers and the function for cooling and heating are controlled effectively.

It is recommended that the research is furthered for enhancing the performance of these HVACS because thermal comfort is a basic factor that influences the total energy consumption demand in buildings. In the future, the authors will further this research to evaluate the gas emission dispersion and its influence on the battery room. It will further enhance the performance of the HVACS since the gas dispersion emission angle may influence the operation of safety devices within the battery housing room. The research future trend shows that more intelligent controls will play a significant role in enhancing energy savings and influence the economic benefits, which includes diagnosis of HVAC faults, savings of energy, and making sure that all pieces of equipment operate accordingly.

Author Contributions: Conceptualisation, M.J.L., S.D.C. and S.M.; Methodology, M.J.L., S.D.C. and S.M.; Validation, M.J.L., S.D.C., L.N., S.M. and M.S.; formal analysis, M.J.L., S.D.C. and S.M.; investigation, M.J.L., S.D.C. and S.M.; resources, M.J.L., S.M.; data curation, M.J.L., S.D.C. and S.M.; writing-original draft preparation, M.J.L., S.D.C.; writing-review and editing, M.J.L., S.D.C., S.M., M.S. and L.N.; visualisation, M.J.L., S.D.C., S.M. and L.N. All authors have read and agreed to the published version of the manuscript.

Funding: This research received no external funding.

Institutional Review Board Statement: Not applicable.

Informed Consent Statement: The authors hereby agree to publish this paper as Co-Authors in the sequence of Names as above on the basis of our (1) contributions and participations in formulating the research problem, or analysing and interpreting the data or have made other substantial scholarly effort or a combination of these; and/or (2) participations in writing the paper; and (3) approvals of the final version for publication.

Data Availability Statement: Not applicable.

Acknowledgments: The authors would like to thankfully appreciate the Tshwane University of Technology, Pretoria, South Africa, Enviroware Construction, South Africa, and Eskom for providing the necessary infrastructure and support to conduct this research study.

Conflicts of Interest: The authors declare no conflict of interest.

$\begin{array}{ll}\text { Abbreviations } \\ \text { AGM } & \text { Absorbed Glass Matt } \\ \text { Ah } & \text { Ampere hour } \\ \text { AHU } & \text { Air-Handling Unit } \\ \text { DRL } & \text { Deep Reinforcement Learning } \\ \text { ENN } & \text { Elman Network Neural } \\ \text { FIS } & \text { Fuzzy Inference System } \\ \text { HDTT } & \text { Humidity Duct Temperature Transmitter } \\ \text { HVACS } & \text { Heating Ventilation Air Conditioning System } \\ \text { IEEE } & \text { Institute for Electronic and Electrical Engineers } \\ \text { IS } & \text { Intrinsic Safety } \\ \text { LAB } & \text { Lead-Acid Batteries } \\ \text { LEL } & \text { Lower Explosive Limit }\end{array}$




$\begin{array}{ll}\text { LFL } & \text { Lower Flammability Level } \\ \text { LSTM } & \text { Long Short-Term-Memory } \\ \text { MPC } & \text { Microprocessor-based programmable controller } \\ \text { NCP } & \text { Network Control Panel } \\ \text { PI } & \text { Proportional-integral } \\ \text { PID } & \text { Proportional-Integration-Derivative } \\ \text { PPD } & \text { Predicted Percentage of Discomfort } \\ \text { RL } & \text { Reinforcement Learning } \\ \text { SDRE } & \text { State-Dependent-Riccati-Equation } \\ \text { SUT } & \text { Scaled Unscented Transformation } \\ \text { TDNN } & \text { Time-Delay-Neural Network } \\ \text { UKF } & \text { Unscented Kalman Filter } \\ \text { UPS } & \text { Uninterruptible Power Supply } \\ \text { VAV } & \text { Variable Air Volume } \\ \text { VRLA } & \text { Valve Regulated Lead-Acid }\end{array}$

\section{Appendix A. Approved User Requirement Specification}

\section{i. Functional specification}

The HVAC control panel shall be installed to control the air-handling unit (AHU) to ensure that the suitable temperature in the battery room is served shall be kept constant $25 \pm 1{ }^{\circ} \mathrm{C}$. Air used for ventilating battery room shall not exceed $26^{\circ} \mathrm{C}$. The panel will ensure that there is no return air from the battery room to the AHU. There are two exhaust air fans (run and standby). The exhaust fans of the battery room should run all the timechanging each other. When there is no air flowing, the motor must stop and the heater must go off for safety's sake. All battery room critical alarms shall be sent to the control desk. All safety alarming and indications shall be fail-safe; thus, even when the detecting equipment fails, the alarm will be triggered, such as no airflow, very high or low temperature, and smoke detection.

\section{ii. Non-functional requirements}

The panel is a top entry and top exit for the cable, the panel must be installed under a roof. The degree of protection for the panel is (IP rating of 3X), which means it is $50 \%$ protected against the dust and has no protection against water, hence the place of installation must be clean with no drops of water. The sheet metal must be 2-mm thick in case it falls, and the components inside must not get damaged.

\section{Appendix B. Equation Derivation}

Below equations describe the derivations of Equations (1) through (10);

$$
\Delta_{\text {s.g. }}=\frac{\frac{V_{p}}{n_{c}}}{N_{s}}-s . g .=V_{c_{a v g}}-s . g . ;
$$

where $V_{p}$ represent the bus voltage imposed in the battery string, $N_{S}$ stands for the number of parallel strings, and $V_{\mathcal{C}_{\text {avg }}}$ stand for the average voltage imposed across the cell, whereas $\Delta_{\text {s.g. }}$. represent the difference between the average and fully charged specific gravity of the cell. Therefore, the below equations pertains as described by Equations (1)-(10);

$$
\begin{aligned}
& H 2-V R L A @ 25^{\circ} \mathrm{C}=n c \times C 8 \times 1.11 \times 10-18 \times e^{(15 \times \Delta \text { s.g. })} \\
& =n c \times C 8 \times 1.11 \times 10-18 \times e^{(15 \times 0.980)} \\
& =n c \times C 8 \times 2.69 \times 10-11
\end{aligned}
$$

Therefore, for a heat generation, the following equations are derived as described in [62];

$$
q_{\text {rev }}=I \times t \times T_{K} \times \Delta S ;
$$


where $q_{\text {rev }}$ stands for the heat reaction in Joules, $I$ is the average current available in a cell in amperes, $t$ represent the charge/discharge time in hours, $T_{K}$ stands for the temperature at the beginning of the discharge in Kelvin, and $\Delta S$ represents the entropy of reaction in Joules/mole-K.

Therefore, Equation (14) can be improved to make it understandable for battery specialists and is represented by Equation (15) below;

$$
q_{r e v-w h}=E_{A h} \times n_{c / s} \times \Delta S_{T} ;
$$

where $q_{\text {rev-wh }}$ represent the heat reaction in watthours, $E_{A h}$ stands for ampere-hours of charge/discharge, $n_{c / s}$ represent the number of cells per string, and $\Delta S_{T}$ represent the entropy of reaction in $\mathrm{Wh} / \mathrm{Ah}$ at $25^{\circ} \mathrm{C}$.

Thus, the total heat generation can be described as;

$$
\begin{gathered}
q_{w}=q_{r e v}+q_{J} ; \\
q_{w}=q_{r e v}+q_{J-r}+q_{J-c}+q_{J-o}
\end{gathered}
$$

where $q_{J-r}$ is the total joule effect heat reaction, $q_{J-c}$ represents the total joule effect heat from electrolysis reaction, and $q_{J-o}$ stands for the total Joule effect heat from oxygen recombination.

Therefore, considering the battery operating modes as indicated in Section 2 of this paper, the following arises;

$$
\begin{aligned}
q_{w-V R L A} & =n_{c} \times(((I \times 0.83) \times(0.135))+(I \times 1.1 \times 0.09 \times 2.30)) ; \\
& =n_{c} \times I \times 0.34
\end{aligned}
$$

Therefore, for a boost charge, the maximum difference between average cell finishing charge voltage and cell open-circuit voltage for a VRLA cell would be $0.255 \mathrm{~V}$ (e.g., 2.40 $\mathrm{V} /$ cell finishing charge for a $2.145 \mathrm{~V}$ open-circuit voltage on a $1.300 \mathrm{s.g}$. cell);

$$
\begin{aligned}
q_{w-\text { for a boost charge }} & =t \times n_{c} \times(((I \times 0.83) \times(0.255))+(I \times 1.1 \times 0.09 \times 2.4)) \\
& =t \times n_{c} \times 0.449
\end{aligned}
$$

Thus, for a bulk charge, the following equations yield

$$
\begin{gathered}
q_{w h}=q_{\text {rev }}+q_{J-r-\text { charge }} \\
q_{w h-P b-\text { charge }}=\left(I \times t \times n_{c} \times \Delta S_{T}\right)+\left(I \times K_{A M} \times t \times n_{c} \times\left(V_{c-\text { charge }}-V_{c-o c v}\right)\right) ; \\
t=K_{b-r} \times \frac{C_{r-s}}{I} ; \\
C_{r-s}=I_{\text {disharge }-s} \times t_{\text {discharge }} ; \\
\Delta S_{T}=(-0.227 \times(\text { s.g. }))+0.351 ;
\end{gathered}
$$

where $K_{b-r}$ represent the percentage of battery SoC before side reaction starts and $C_{r-s}$ stands for the ampere-hours removed (/string) during discharge that must be replaced.

The maximum difference between average cell float voltage and cell open-circuit voltage for a VRLA would be $0.135 \mathrm{~V}$ (e.g., $2.28 \mathrm{~V} /$ cell float for a $2.145 \mathrm{~V}$ open-circuit voltage on a $1.300 \mathrm{s.g}$. cell). Subclause B.2.3.1.1 points out that $\mathrm{Kb}-\mathrm{r}$ is approximately 0.80 for VRLA batteries, and Table B.2 expresses KAM as 0.91 as stated in [62]. The highest specific gravity used in VRLA technology is 1.325 . Substituting these values leads to the following equation:

$$
q_{w h}=C_{r-s} \times n_{c} \times 0.138 ;
$$


Consequently, to determine the heat generation during thermal runaway, equations below are derived as:

$$
\begin{gathered}
q_{w-P b-S b-T R}=q_{J-r}+q_{J-c} \\
=n c \times I \times K A m \times V c-T R-V c-o c v+I \times K o c v \times V c-T R-V c \\
q w=n c \times I \times 0.91 \times 2.54-2.145+I \times 0.09 \times 2.54-1.48 \\
=n c \times I \times 0.455
\end{gathered}
$$

where $V_{c-T R}$ is the average voltage across a cell during a thermal runaway event.

\section{References}

1. Mahlangu, S.; Sibanyoni, M.; Ngoma, L.; Chowdhury, S.P.D. The Design of HVAC Network Control Panel For Battery Room. In Proceedings of the 2020 6th IEEE International Energy Conference (ENERGYCon), Gammarth, Tunisia, 28 September-1 October 2020; pp. 787-791. [CrossRef]

2. Magenes, L.; Dinh, H.Q.; Klein, A. How New Energy Codes Impact Electrical Substation Designs: An Overview of the Changing Regulations. IEEE Ind. Appl. Mag. 2020, 26, 21-28. [CrossRef]

3. Schismenos, S.; Chalaris, M.; Stevens, G. Battery hazards and safety: A scoping review for lead acid and silver-zinc batteries. Saf. Sci. 2021, 140, 105290. [CrossRef]

4. Zelinsky, M.A.; Koch, J.M.; Young, K.-H. Performance Comparison of Rechargeable Batteries for Stationary Applications (Ni/MH vs. Ni-Cd and VRLA). Batteries 2018, 4, 1. [CrossRef]

5. Parker, T.; Obeng, L.; Wang, Q. Fire Hazard Assessment of Lead-Acid Batteries. 2020. p. 20. Available online: https://www.nfpa. $\mathrm{org} /$ - /media/Files/News-and-Research/Fire-statistics-and-reports/Hazardous-materials/RFLeadAcidBattery.pdf (accessed on 15 May 2021).

6. Ziganshin, A.D.; Safiullin, L.S.; Bogatkin, A.V.; Pavlov, P.P.; Gatiyatov, I.Z.; Auhadeev, A.E. Particular properties of operation of stationary lead-acid batteries at power distribution facilities. In IOP Conference Series: Materials Science and Engineering; IOP Publishing: Bristol, UK, 2019; Volume 570, p. 012105. [CrossRef]

7. Roselli, C.; Sasso, M.; Tariello, F. Assessment of a solar PV-driven desiccant-based air handling unit with different tracking systems. Sustain. Energy Technol. Assess. 2019, 34, 146-156. [CrossRef]

8. Setayesh, H.; Moradi, H.; Alasty, A. Nonlinear robust control of air handling units to improve the indoor air quality \& $\mathrm{CO}_{2}$ concentration: A comparison between $\mathrm{H} \infty$ \& decoupled sliding mode controls. Appl. Therm. Eng. 2019, 160, 113958. [CrossRef]

9. Bellofatto, L. Advantages and challenges of modular solutions for electrical substations. In Proceedings of the 2019 Petroleum and Chemical Industry Conference Europe (PCIC EUROPE), Paris, France, 7-9 May 2019; pp. 1-7.

10. Parra, G.; Komathy, J.; Clement, G.; Anderson, R. Substations in Classified Locations: Integration of NFPA 496 Pressurization Requirements with Other Supporting Systems: Copyright Material IEEE, Paper No. PCIC-2018-44. In Proceedings of the 2018 IEEE Petroleum and Chemical Industry Technical Conference (PCIC), Cincinnati, OH, USA, 24-26 September 2018 ; pp. 389-398. [CrossRef]

11. Parra, G.; Komathy, J.; Clement, G.J.; Anderson, R.P. Substations in Classified Locations: Integration of Pressurization Requirements With Other Supporting Systems. IEEE Ind. Appl. Mag. 2021, 27, 82-93. [CrossRef]

12. Perng, J.-W.; Kuo, Y.-C.; Chang, Y.-T.; Chang, H.-H. Power Substation Construction and Ventilation System Co-Designed Using Particle Swarm Optimization. Energies 2020, 13, 2314. [CrossRef]

13. Martinaitis, V.; Streckiene, G.; Bagdanavicius, A.; Bielskus, J. A comparative thermodynamic analysis of air handling units at variable reference temperature. Appl. Therm. Eng. 2018, 143, 385-395. [CrossRef]

14. Lee, J.M.; Hong, S.H.; Seo, B.M.; Lee, K.H. Application of artificial neural networks for optimized AHU discharge air temperature set-point and minimized cooling energy in VAV system. Appl. Therm. Eng. 2019, 153, 726-738. [CrossRef]

15. Zou, Z.; Yu, X.; Ergan, S. Towards optimal control of air handling units using deep reinforcement learning and recurrent neural network. Build. Environ. 2020, 168, 106535. [CrossRef]

16. Liu, W.; Kalbasi, R.; Afrand, M. Solutions for enhancement of energy and exergy efficiencies in air handling units. J. Clean. Prod. 2020, 257, 120565. [CrossRef]

17. Kaam, S.; Raftery, P.; Cheng, H.; Paliaga, G.; Chen, H. Time-averaged ventilation for optimized control of variable-air-volume systems. Energy Build. 2017, 139, 465-475. [CrossRef]

18. Li, X.; Han, Z.; Zhao, T.; Zhang, J.; Xue, D. Modeling for indoor temperature prediction based on time-delay and Elman neural network in air conditioning system. J. Build. Eng. 2021, 33, 101854. [CrossRef]

19. Liu, Z.; Li, W.; Chen, Y.; Luo, Y.; Zhang, L. Review of energy conservation technologies for fresh air supply in zero energy buildings. Appl. Therm. Eng. 2019, 148, 544-556. [CrossRef]

20. Liu, B.; Akcakaya, M.; Mcdermott, T.E. Automated Control of Transactive HVACs in Energy Distribution Systems. IEEE Trans. Smart Grid 2021, 12, 2462-2471. [CrossRef]

21. Han, O.; Zhang, Y.; Li, A.; Li, J.; Li, Y.; Liu, H. Experimental and numerical study on heavy gas contaminant dispersion and ventilation design for industrial buildings. Sustain. Cities Soc. 2020, 55, 102016. [CrossRef] 
22. Brzezińska, D. Ventilation System Influence on Hydrogen Explosion Hazards in Industrial Lead-Acid Battery Rooms. Energies 2018, 11, 2086. [CrossRef]

23. Brzezinska, D. Hydrogen Explosion Hazards Limitation in Battery Rooms with Different Ventilation Systems. September 2019. Available online: https:/ / www.h2knowledgecentre.com/content/conference998 (accessed on 15 May 2021).

24. Chintala, R.H. A Methodology for Automating the Implementation of Advanced Control Algorithms Such as Model Predictive Control on Large Scale Building HVAC Systems. Ph.D. Thesis, Texas A \& M University, College Station, TX, USA, 2018. Available online: https:/ / oaktrust.library.tamu.edu/handle/1969.1/173325 (accessed on 20 May 2021).

25. Overgaard, A. Reinforcement Learning for Building Heating via Mixing Loops. Ph.D. Thesis, Aalborg University, Aalborg, Denmark, 2019.

26. Rawlings, J.B.; Patel, N.R.; Risbeck, M.J.; Maravelias, C.T.; Wenzel, M.J.; Turney, R.D. Economic MPC and real-time decision making with application to large-scale HVAC energy systems. Comput. Chem. Eng. 2018, 114, 89-98. [CrossRef]

27. Ahn, J.; Cho, S.; Chung, D.H. Analysis of energy and control efficiencies of fuzzy logic and artificial neural network technologies in the heating energy supply system responding to the changes of user demands. Appl. Energy 2017, 190, 222-231. [CrossRef]

28. Perekrest, A.; Shendryk, V.; Pijarski, P.; Parfenenko, Y.; Shendryk, S. Complex information and technical solutions for energy management of municipal energetics. In Proceedings of the Photonics Applications in Astronomy, Communications, Industry, and High Energy Physics Experiments 2017, Wilga, Poland, 7 August 2017; Volume 10445, p. 1044567. [CrossRef]

29. Qiang, F.; Qiansu, L.; Yuanyuan, C.; Bowen, L.; Xu, W.; Haibo, J.; Jiyan, Q.; Wei, G.; Tingyun, G.; Lei, C.; et al. Development and Application of Environmental Regulation and Control System in Substation Distribution Room. In Proceedings of the 2019 IEEE 3rd Information Technology, Networking, Electronic and Automation Control Conference (ITNEC), Chengdu, China, 15-17 March 2019; pp. 1784-1788. [CrossRef]

30. Shah, A.; Huang, D.; Chen, Y.; Kang, X.; Qin, N. Robust Sliding Mode Control of Air Handling Unit for Energy Efficiency Enhancement. Energies 2017, 10, 1815. [CrossRef]

31. Liavoli, F.B.; Fakharian, A. Sub-Optimal Observer-based Controller Design Using the State Dependent Riccati Equation Approach for Air-Handling Unit. In Proceedings of the 2019 27th Iranian Conference on Electrical Engineering (ICEE), Yazd, Iran, 30 April-2 May 2019; pp. 991-996. [CrossRef]

32. Hong, G.; Kim, B.S. Development of a Data-Driven Predictive Model of Supply Air Temperature in an Air-Handling Unit for Conserving Energy. Energies 2018, 11, 407. [CrossRef]

33. Kanaka, S.A. Temperature Control Using an Air Handling Unit Installed with Carel pCO5+ Controller. 2018. Available online: https: / / recipp.ipp.pt/handle/10400.22/14219 (accessed on 26 July 2021).

34. Kurilla, J. Temperature control of multidimensional system using decoupled MPC controllers. In Proceedings of the $201721 \mathrm{st}$ International Conference on Process Control (PC), Strbske Pleso, Slovakia, 6-9 June 2017; pp. 351-357. [CrossRef]

35. Gunay, H.B.; Newsham, G.; Ashouri, A.; Wilton, I. Deriving sequences of operation for air handling units through building performance optimization. J. Build. Perform. Simul. 2020, 13, 501-515. [CrossRef]

36. Zhuang, J.; Chen, Y.; Wu, J. Cascade control for supply air temperature in a variable air volume system. In IOP Conference Series: Earth and Environmental Science; IOP Publishing: Bristol, UK, 2019; Volume 238, p. 012021. [CrossRef]

37. Gao, J.; Xu, X.; Li, X.; Zhang, J.; Zhang, Y.; Wei, G. Model-based space temperature cascade control for constant air volume air-conditioning system. Build. Environ. 2018, 145, 308-318. [CrossRef]

38. Abdo-Allah, A.; Iqbal, T.; Pope, K. Modeling, Analysis, and Design of a Fuzzy Logic Controller for an AHU in the S.J. Carew Building at Memorial University. J. Energy 2018, 2018, e4540387. [CrossRef]

39. Oleolo, I.; Abdullah, H.; Mohamad, M.; Jaafar, M.N.M.; Baharain, A.; Sulaiman, S. Multi-Circuit Air-Conditioning System Modelling for Temperature Control. J. Adv. Res. Fluid Mech. Therm. Sci. 2021, 83, 14-24. [CrossRef]

40. Fiorentini, M.; Wall, J.; Ma, Z.; Braslavsky, J.; Cooper, P. Hybrid model predictive control of a residential HVAC system with on-site thermal energy generation and storage. Appl. Energy 2017, 187, 465-479. [CrossRef]

41. Yang, S.; Wan, M.; Chen, W.; Ng, B.F.; Dubey, S. Experimental study of model predictive control for an air-conditioning system with dedicated outdoor air system. Appl. Energy 2020, 257, 113920. [CrossRef]

42. Afram, A.; Janabi-Sharifi, F. Supervisory model predictive controller (MPC) for residential HVAC systems: Implementation and experimentation on archetype sustainable house in Toronto. Energy Build. 2017, 154, 268-282. [CrossRef]

43. Erfani, A.; Rajabi-Ghahnaviyeh, A.; Boroushaki, M. Design and construction of a non-linear model predictive controller for building's cooling system. Build. Environ. 2018, 133, 237-245. [CrossRef]

44. Raman, N.S.; Devaprasad, K.; Chen, B.; Ingley, H.A.; Barooah, P. Model predictive control for energy-efficient HVAC operation with humidity and latent heat considerations. Appl. Energy 2020, 279, 115765. [CrossRef]

45. Berouinev, A.; Ouladsine, R.; Bakhouya, M.; Lachhab, F.; Essaaidi, M. A Model Predictive Approach for Ventilation System Control in Energy Efficient Buildings. In Proceedings of the 2019 4th World Conference on Complex Systems (WCCS), Ouarzazate, Morocco, 22-25 April 2019; pp. 1-6. [CrossRef]

46. Kurrila, J.; Hubinský, P. Model predictive control of room temperature with disturbance compensation. J. Electr. Eng. 2017, 68, 312-317. [CrossRef]

47. Grygierek, K.; Ferdyn-Grygierek, J. Multi-Objectives Optimization of Ventilation Controllers for Passive Cooling in Residential Buildings. Sensors 2018, 18, 1144. [CrossRef] 
48. Li, W.; Wang, S. A multi-agent based distributed approach for optimal control of multi-zone ventilation systems considering indoor air quality and energy use. Appl. Energy 2020, 275, 115371. [CrossRef]

49. Shah, A.; Huang, D.; Huang, T.; Farid, U. Optimization of BuildingsEnergy Consumption by Designing Sliding Mode Control for Multizone VAV Air Conditioning Systems. Energies 2018, 11, 2911. [CrossRef]

50. Zhang, J. Design of a new PID controller using predictive functional control optimization for chamber pressure in a coke furnace. ISA Trans. 2017, 67, 208-214. [CrossRef] [PubMed]

51. Schito, E.; Conti, P.; Urbanucci, L.; Testi, D. Multi-objective optimization of HVAC control in museum environment for artwork preservation, visitors' thermal comfort and energy efficiency. Build. Environ. 2020, 180, 107018. [CrossRef]

52. He, D.; Xiong, Q.; Jiang, Z. A Novel VAV Air Conditioning Control System Based on Swarm Intelligence. In Proceedings of the 2020 39th Chinese Control Conference (CCC), Shenyang, China, 27-29 July 2020; pp. 5007-5012. [CrossRef]

53. Ning, M.; Zaheeruddin, M. Neural Network Model-Based Adaptive Control of a VAV-HVAC\&R System. Int. J. Air-Cond. Refrig. 2019, 27, 1950006. [CrossRef]

54. Ali, M. Intelligent Control of HVAC Systems. 2019, p. 230. Available online: https://www.researchgate.net/profile/MohammadAli-52/publication/334593941_Intelligent_Control_of_HVAC_Systems/links/5d3393e14585153e5913cf63/Intelligent-Controlof-HVAC-Systems.pdf (accessed on 27 July 2021).

55. Wang, W.; Chen, J.; Huang, G.; Lu, Y. Energy efficient HVAC control for an IPS-enabled large space in commercial buildings through dynamic spatial occupancy distribution. Appl. Energy 2017, 207, 305-323. [CrossRef]

56. Bay, C.J.; Chintala, R.; Rasmussen, B.P. Steady-State Predictive Optimal Control of Integrated Building Energy Systems Using a Mixed Economic and Occupant Comfort Focused Objective Function. Energies 2020, 13, 2922. [CrossRef]

57. Homod, R.Z.; Gaeid, K.S.; Dawood, S.M.; Hatami, A.; Sahari, K.S. Evaluation of energy-saving potential for optimal time response of HVAC control system in smart buildings. Appl. Energy 2020, 271, 115255. [CrossRef]

58. Yao, L.; Huang, J.-H. Multi-Objective Optimization of Energy Saving Control for Air Conditioning System in Data Center. Energies 2019, 12, 1474. [CrossRef]

59. Seong, N.-C.; Kim, J.-H.; Choi, W. Optimal Control Strategy for Variable Air Volume Air-Conditioning Systems Using Genetic Algorithms. Sustainability 2019, 11, 5122. [CrossRef]

60. Zhao, Z.; Yu, N. The application of advanced control technologies in air conditioning system-A review. Adv. Build. Energy Res. 2015, 11, 52-66. [CrossRef]

61. Mulder, M.; RE, L.; Madiba, P. Design Guide for Power Station Battery Rooms. Eskom 2015, 1-29.

62. IEEE/ASHRAE Guide for the Ventilation and Thermal Management of Batteries for Stationary Applications. In IEEE Std 16352018ASHRAE Guidel. 21-2018 Revis. IEEE Std 1635-2012 ASHRAE Guidel. 21-2012; IEEE: Piscataway, NJ, USA, 2018; pp. 1-116. [CrossRef]

63. Liavoli, F.B.; Fakharian, A. Nonlinear optimal control of air handling unit via State Dependent Riccati Equation approach. In Proceedings of the 2017 5th International Conference on Control, Instrumentation, and Automation (ICCIA), Shiraz, Iran, 21-23 November 2017; pp. 138-143. [CrossRef]

64. Azarbani, A.; Abbasi, R. Optimal State Estimation of Air Handling Unit System without Humidity Sensor using Unscented Kalman Filter. In Proceedings of the 2019 6th International Conference on Control, Instrumentation and Automation (ICCIA), Sanandaj, Iran, 30-31 October 2019; pp. 1-6. [CrossRef]

65. Yuan, S.; Zhang, L.; Holub, O.; Baldi, S. Switched Adaptive Control of Air Handling Units With Discrete and Saturated Actuators. IEEE Control Syst. Lett. 2018, 2, 417-422. [CrossRef]

66. Ionesi, A.; Jouffroy, J. On-line parameter estimation of an Air Handling Unit model: Experimental results using the modulating function method. In Proceedings of the 2018 IEEE/ASME International Conference on Advanced Intelligent Mechatronics (AIM), Auckland, New Zealand, 9-12 July 2018; pp. 81-86. [CrossRef]

67. Koehler, S.; Danielson, C.; Borrelli, F. A primal-dual active-set method for distributed model predictive control. Optim. Control. Appl. Methods 2017, 38, 399-419. [CrossRef]

68. Yan, H.; Xia, Y.; Xu, X.; Deng, S.S. Inherent operational characteristics aided fuzzy logic controller for a variable speed direct expansion air conditioning system for simultaneous indoor air temperature and humidity control. Energy Build. 2018, 158, 558-568. [CrossRef]

69. Ahn, J.; Chung, D.H.; Cho, S. Performance analysis of space heating smart control models for energy and control effectiveness in five different climate zones. Build. Environ. 2017, 115, 316-331. [CrossRef]

70. Bahramnia, P.; Rostami, S.M.H.; Wang, J.; Kim, G.-J. Modeling and Controlling of Temperature and Humidity in Building Heating, Ventilating, and Air Conditioning System Using Model Predictive Control. Energies 2019, 12, 4805. [CrossRef]

71. Izawa, A.; Fripp, M. Multi-Objective Control of Air Conditioning Improves Cost, Comfort and System Energy Balance. Energies 2018, 11, 2373. [CrossRef]

72. Collotta, M.; Messineo, A.; Nicolosi, G.; Pau, G. A Dynamic Fuzzy Controller to Meet Thermal Comfort by Using Neural Network Forecasted Parameters as the Input. Energies 2014, 7, 4727-4756. [CrossRef]

73. Wang, Y.; Velswamy, K.; Huang, B. A Long-Short Term Memory Recurrent Neural Network Based Reinforcement Learning Controller for Office Heating Ventilation and Air Conditioning Systems. Processes 2017, 5, 46. [CrossRef]

74. Heidrich, T.; Grobe, J.; Meschede, H.; Hesselbach, J. Economic Multiple Model Predictive Control for HVAC Systems-A Case Study for a Food Manufacturer in Germany. Energies 2018, 11, 3461. [CrossRef] 
75. A Fuzzy Control Strategy Using the Load Forecast for Air Conditioning System-ProQuest. Available online: https://0-wwwproquest-com.tkplib01.tut.ac.za/docview/2422315138/59BDAD87A5DA465APQ/46?accountid=42821 (accessed on 28 July 2021).

76. Alamin, Y.I.; Castilla, M.D.M.; Álvarez, J.D.; Ruano, A. An Economic Model-Based Predictive Control to Manage the Users' Thermal Comfort in a Building. Energies 2017, 10, 321. [CrossRef]

77. Nasruddin; Sholahudin; Satrio, P.; Mahlia, T.M.I.; Giannetti, N.; Saito, K. Optimization of HVAC system energy consumption in a building using artificial neural network and multi-objective genetic algorithm. Sustain. Energy Technol. Assess. 2019, 35, 48-57. [CrossRef]

78. Yang, S.; Wan, M.P.; Chen, W.; Ng, B.F.; Dubey, S. Experiment study of machine-learning-based approximate model predictive control for energy-efficient building control. Appl. Energy 2021, 288, 116648. [CrossRef]

79. Carrascal-Lekunberri, E.; Garrido, I.; Van Der Heijde, B.; Garrido, A.J.; Sala, J.M.; Helsen, L. Energy Conservation in an Office Building Using an Enhanced Blind System Control. Energies 2017, 10, 196. [CrossRef]

80. Mei, J.; Xia, X. Energy-efficient predictive control of indoor thermal comfort and air quality in a direct expansion air conditioning system. Appl. Energy 2017, 195, 439-452. [CrossRef]

81. Behrooz, F.; Mariun, N.; Marhaban, M.H.; Radzi, M.A.M.; Ramli, A.R. Review of Control Techniques for HVAC SystemsNonlinearity Approaches Based on Fuzzy Cognitive Maps. Energies 2018, 11, 495. [CrossRef]

82. Lv, R.; Yuan, Z.; Lei, B.; Zheng, J.; Luo, X. Model Predictive Control with Adaptive Building Model for Heating Using the Hybrid Air-Conditioning System in a Railway Station. Energies 2021, 14, 1996. [CrossRef]

83. Dhar, N.K.; Verma, N.K.; Behera, L. Adaptive Critic-Based Event-Triggered Control for HVAC System. IEEE Trans. Ind. Inform. 2017, 14, 178-188. [CrossRef]

84. Ostadijafari, M.; Dubey, A. Tube-Based Model Predictive Controller for Building's Heating Ventilation and Air Conditioning (HVAC) System. IEEE Syst. J. 2020, 1-10. [CrossRef]

85. Zhang, X.; Shi, W.; Yan, B.; Malkawi, A.; Li, N. Decentralized and Distributed Temperature Control via HVAC Systems in Energy Efficient Buildings. arXiv 2017, arXiv:1702.03308. Available online: http:/ /arxiv.org/abs/1702.03308 (accessed on 11 June 2021).

86. Afram, A.; Janabi-Sharifi, F.; Fung, A.S.; Raahemifar, K. Artificial neural network (ANN) based model predictive control (MPC) and optimization of HVAC systems: A state of the art review and case study of a residential HVAC system. Energy Build. 2017, 141, 96-113. [CrossRef]

87. Smart Room Control Solutions | Products | Distech Controls. DistechControls. Available online: https://www.distech-controls. com/products / family / room-control-solution (accessed on 25 July 2021). 